\title{
РОЗВИТОК ПРОФЕСІЙНО ЗНАЧУЩИХ ЯКОСТЕЙ МАЙБУТНІХ МЕНЕДЖЕРІВ ОРГАНІЗАЦІЙ ЗАСОБАМИ ПСИХОЛОГІЧНОГО ТРЕНІНГУ
}

\section{Діденко Марина Сергї̈вна}

Стариий викладач кафедри психології та особи стісного розвитку Навчально-наукового інституту менеджменту та психологї Державного вишого навчального закладу «Університет менеджменту освіти» Національної академії педагогічних наук України, м. Київ (Украӥна)

ORCID ID: https://orcid.org/0000-0001-8386-6755

\begin{abstract}
Анотація. Стаття присвячена опису процесу керованого розвитку професійно значущих якостей майбутніх менеджерів у процесі здобуття вищої освіти. Надаються організаційно-методичні рекомендащіï щцодо організащіï та змістового наповнення тренінгової програми. Процес організації та проведення тренінгових занять зі студентами-менеджерами в процесі навчання. Акцент в тренінговій програмі зроблено на розвиток комунікативного компоненту професійно значущих якостей майбутніх менеджерів, у зв'язку з тим, щзо більшість респондентів при констатувальному експерименті саме в ньому вбачають найбільші прогалини свого розвитку $і$ надають йому першорядного значення прогнозуючи свою майбутню діяльність. В статті описано 3 модулі тренінгової програми спрямовані на 3 змістових компоненти: розвиток комунікативних умінь, асертивності та стилю реагування в конфліктних ситуащіях, розраховані на три одноденних тренінги та ряд домашніх завдань.
\end{abstract}

Ключові слова: якість особистості, студенти-менеджери, професійно значущі якості, розвиток, психологічний тренінг, комунікативний компонент.

Постановка проблеми. На сьогоднішній день питання конкурентоспроможності на ринку праці стоїть дуже гостро для українських випускників. Отримуючи диплом про вищу освіту випускник має певні теоретичні знання які не завжди відповідають викликам 3 якими він зіштовхнеться в професійному жит- тя. I один з можливих шляхів вирішення цієї проблеми на нашу думку, є розвиток професійно значущих якостей майбутніх фахівців. Це дозволить випускникам швидко адаптуватись до вимог роботодавців, нових умов функціонування та професійно здійснювати свої робочі функції. На жаль система освіти побу- 
дована таким чином, що основний акцент у навчанні зроблений на засвоєння професійних знань 3 певної галузі, і це безумовно важливо, але ще важливішим є приділення особливої уваги розвитку професійно значущих якостей особистості, що можливо зроби за допомогою посилення психологічної складової навчального процесу, за допомогою введення спеціальних спецкурсів, семінарських, розробкою та проведенням психологічних тренінгів на відповідну тематику.

Аналіз останніх досліджень та публікацій $з$ проблеми. В сучасній науці існує цілий пласт досліджень специфіки розвитку та формування професійно значущих якостей особистості як загального, так і специфічного спрямування, що представлений працями таких вчених: як: Т. В. Баталова [3], Л. Карамушка [10], С. Максименко [12], Л. Орбан-Лембрик [13], А. Теймуразян [16], Н. Чепелєва [19], та ін. Вивченню якостей успішного керівника/менеджера приділяли увагу А. Доброскок [9], Ю. Бачинська [4], М. Вудкок[5], В. Панченко [14], L. R. Goldberg [20], P. J. Howard [21] та інші.

Метою статті $\epsilon$ розкриття психологічних механізмів розвитку професійно значущих якостей майбутніх менеджерів організацій в процесі здобуття фахової освіти засобами психологічного тренінгу та представлення розроблення тренінгової програми.

Виклад основного матеріалу. Розвиток професійно значущих якостей (ПЗЯ) май- бутніх менеджерів ми пропонуємо здійснювати за допомогою спеціально розробленої тренінгової програми, яка спрямованої на розвиток комунікативного компоненту ПЗЯ майбутніх менеджерів. Це зумовлено тим, що, поперше, саме комунікативний компонент за результатами проведеного факторного аналізу посів перше місце в ієрархії ПЗЯ майбутніх менеджерів на всіх етапах навчального процесу. По-друге, на констатувальному етапі дослідження аналіз результатів очікування майбутніх менеджерів від професії (за проективною методикою) виявив, що більшість респондентів серед найбільших труднощів у майбутній роботі вбачають можливі проблеми 3 комунікаціями в колективі, з підлеглими чи керівництвом. Відповідно до цього, нами було обрано комунікативний компонент ПЗЯ майбутніх менеджерів, як той компонент, вплив на який максимально швидко наблизить майбутніх менеджерів до рівня «менеджерпрофесіонал».

Беручи до уваги той факт, що в процесі здійснення навчального процесу проведення одного кількаденного тренінгу як правило не можливо, нам здається доцільним варіантом проведення батареї окремих практичних занять (з трьох модулів) з елементами соціально-психологічного тренінгу. Батарея практичних занять складалася 3 трьох одноденних тренінгів (один раз на тиждень по шість годин), а також 3 двох самостійних домашніх завдань, на які було заплановано дев'ять і три 
години відповідно.

Перший модуль був спрямований на розвиток комунікативних здібностей майбутніх менеджерів, другий - на розвиток їхньої асертивності, а третій - на формування оптимальних i ефективних стратегій розв'язання конфліктних ситуацій. Таким чином загальна кількість годин, спрямована на розвиток комунікативного компоненту ПЗЯ майбутніх менеджерів становила 30 годин (1 кредит), що дає змогу здійснити комплексний вплив і запустити процес трансформацій даного компоненту, що в свою чергу наблизить майбутніх менеджерів до рівня «менеджер-професіонал». Варто окремо зазначити, що всі завдання програми були побудовані з урахуванням специфіки майбутньої професійної діяльності менеджерів і грунтувалися на реальних управлінських кейсах.

Зміст практично-тренінгового заняття був вибудований таким чином, щоб надати можливість учасникам максимально розкрити свої комунікативні здібності у форматі майбутньої професійної діяльності, допомогти їм подолати свої острахи і надати інструменти для ефективної комунікації.

Цільова аудиторія. Тренінг розраховано перш за все на студентів, що обрали спеціальність менеджмент. Проводити його можна як для студентів молодших курсів, так і для студентів випускних курсів - тренінгові вправи можна використовувати як ефективний засіб практичного закріплення набутих раніше теоретичних знань.

Видається логічним надати програму розвитку комунікативного компоненту ПЗЯ майбутніх менеджерів.

Перший модуль практичних занять був спрямований на розкриття комунікативних здібностей випробуваних і передбачав п'ятнадцять годин практики, з яких шість годин навчання проходило у вигляді тренінгових занять, а дев'ять у вигляді домашньої самостійної роботи.

Отже, розпочалось заняття першого модулю 3 вправи на знайомство «Візитка», в якій кожному з учасників було запропоновано назвати своє ім'я й охарактеризувати себе трьома словами, обгрунтувавши їх значення.

Після першої вправи учасники тренінгу озвучують свої очікування від тренінгу; тренер співставляє очікування учасників 3 цілями i завданнями тренінгу, корегує за потреби програму тренінгу; учасники обговорюють і й приймають правила роботи групи.

Після знайомства учасники прослухають міні-лекцію «Комунікація як функція менеджера» про значення ефективної комунікації у професійній діяльності менеджера, іiї особливості й різновиди. Учасники також мали змогу обговорити ключові моменти лекції, висловити свою думку щодо значення комунікації в роботі менеджера.

Надалі студентам була запропонована вправа «Сірники», що мала на меті напрацювати навички формулювання чітких задач, мо- 
делюючи взаємодію менеджер-підлеглий.

Наступна вправа - «Зіпсований телефон» - класична вправа на розвиток комунікативних вмінь, мала на меті продемонструвати бар'єри і труднощі, які виникають у професійному спілкуванні. За умовами вправи, учасник повинен передати запропоноване повідомлення сусіду справа, але не повторюючи при цьому жодного із використаних у повідомленні слів. Обговорюючи результати вправи, учасники мали змогу поміркувати над тим, чому істотно змінюється зміст інформації або завдання при їх передачі від, наприклад, директора до безпосереднього виконавця; які саме фактори на це впливають; які це має наслідки; і як можна уникнути викривлення змісту інформації.

Вправа «Вавилонська вежа», яка проводилася далі, була спрямована на підвищення рівня згуртування і взаємодії в групі, розвиток навичок невербальної комунікації.

Вправа - «Автобус» - мала на меті закріпити результати попередньої вправи і навчати учасників використовувати для досягнення мети весь арсенал комунікативних засобів: як вербальних, так і не вербальних.

Після годинного перепочинку студентам було запропоновано вправу «Передати одним словом». Основна мета цієї вправи наголосити на важливості інтонації у процесії комунікації. Учасникам тренінгу надавався перелік емоцій: радість, подив, жаль, розчарування, підозрілість, смуток, веселощі, холодна байдужість, спокій, зацікавленість, впевненість, бажання допомогти, втома, хвилювання, ентузіазм. Згідно цих емоцій необхідно було проговорити «Добрий день». Решта учасників за інтонацією мала вгадати назву самих емоцій [11, с.107-109]. Після проходження вправи учасники тренінгу надавали зворотній зв'язок щодо труднощів і відчуттів під час роботи, визначали важливість використання адекватних емоцій під час виконання професійних завдань.

Наступна вправа - «Моя асоціація» (авторська розробка), мета якої актуалізувати знання учасників про професійно значущі якості менеджерів організацій, виявити їхню професійну самоідентичність. Учасникам необхідно було надати асоціацію на слова 3 переліку, пов'язаного з професійною діяльністю. Перелік слів: людина, діяльність, менеджер, навчання, вибір, менеджмент, спостереження, професія, розвиток, якості, оцінка, викладач, персонал, управління, особистість, професіонал, лідер, керівник, фахівець, я. По завершенню вправи учасники надавали зворотній зв'язок щодо складності виконання вправи, проводили паралелі між власною особистістю і уявленням про менеджера, завдяки асоціаціям намагалися створити портрет успішного менеджера.

Надалі учасникам тренінгу була запропонована вправа «Мозковий штурм на тему «Ефективна комунікація», за якою випробувані методом мозкового штурму обговорювали i 
виявляли правила ефективної комунікації. Під час виконання вправи було визначено, що для ефективного «слухання» необхідно: уважно слухати співрозмовника (колегу, підлеглого, керівника), намагатися зрозуміти підтекст (другий, третій тощо смисл), проявити емпатію; для ефективного «говоріння» - питати думку партнера по комунікації про предмет обговорення, уточнювати міру розуміння власних слів, відкритість до повторення інформації (якщо є відчуття, що співрозмовник не розуміє інформації).

Наступна вправа - «Слухати і чути»[17, с. 100]. Учасникам тренінгу було запропоновано правила ефективного слухання: повна концентрація на співрозмовнику (зосередження уваги не тільки на словах, але й на позі, міміці, жестикуляції), перевірка правильного розуміння слів співрозмовника, відсутність порад і оцінок. Після цього всіх учасників було поділено на пари, де одна особа - доповідач, а друга - слухач. Спочатку доповідач протягом п'яти хвилин розповідає слухачу про свої проблеми і труднощі в спілкуванні. Слухач дотримується правила ефективного слухання і тим самим допомагає доповідачу розповідати про себе. Через п’ять хвилин доповідач впродовж однієї хвилини надає зворотній зв'язок слухачу щодо сприятливих стратегій, вжитих останнім для їхньої успішної комунікації.

Після цього доповідач протягом п’яти хвилин розповідає про свої сильні сторони в спілкуванні, про те, що йому допомагає встановлювати контакти, будувати взаємовідносини 3 іншими. По завершенню слухач за п'ять хвилин повторює доповідачу, що він зрозумів із двох його розповідей (про труднощі і проблеми, а також про сильні сторони в спілкуванні). Впродовж п'яти хвилин доповідач мовчить і тільки рухом голови показує, згодний він або ні з тим, що говорить слухач. Якщо він робить негативний рух головою в знак того, що його неправильно зрозуміли, то слухач повинен поправлятися доти, поки не одержить підтвердження правильності своїх слів. Після того як слухач скаже все, що він запам'ятав із двох розповідей доповідача, останній говорить, що було пропущено або перекручено.

У другій частині вправи учасники пари міняються ролями. Усі чотири кроки вправи повторюються. Під час обговорення вправи учасники надають зворотній зв'язок щодо особливостей виконання запропонованих правил, про складність-легкість розповідей про власні сильні-слабкі сторони, про вплив зворотної реакції партнера по комунікації тощо.

Далі учасники тренінгу пройшли вправу «Подарунок по колу». Мета вправи - створити правильну атмосферу, позитивний клімат та надати ресурс на завершення дня, відпрацювати невербальні навички. Учасники повинні подарувати сусіду зліва умовний подарунок (враження, предмет тощо), враховуючи його інтереси - невербально, шляхом жестів, 
пантоміми.

За допомогою останньої вправи «Реклама» учасники мали змогу відпрацювати навички самопрезентації і презентації продукту своєї компанії.

По завершенню останньої вправи учасники тренінгу надали зворотній зв'язок щодо власних очікувань і здобутих навичок від першого модулю занять, а також отримали домашнє завдання. Домашнє завдання було спрямовано на самостійний аналіз додаткової літератури про комунікативні особливості роботи практиків менеджерів-професіоналів за такими джерелами: Лі Якокка «Кар'єра менеджера», Генрі Форд «Моє життя, мої досягнення», Пітер Друкер «Енциклопедія менеджменту» (на вибір). За опрацьованими джерелами необхідно було зробити портрет успішного менеджера. Портрет можна було зобразити в будь-якій техніці: колаж, опис, твір, перелік рис, схематично. Орієнтовний час виконання домашнього завдання - дев'ять годин.

Другий модуль практичних занять був спрямований на розвиток навичок асертивної поведінки. Перша вправа другого модулю «Повтори за мною» (авторська модифікація) мала на меті створення привітної атмосфери, продовження знайомства. Кожен учасник розказав, чим найбільше любить займатися, яке має хоббі і уподобання. По завершенню учасники тренінгу пригадали основні правила роботи групи.

Далі студенти прослухали міні-лекцію про асертивність й асертивну поведінку, їі особливості й основні правила. Для закріплення інформації було запропоновано вправу «Скажи «Ні», меті якої - розвиток навичок асертивної поведінки та умінь давати аргументовану відмову в ситуації вибору.

Наступною вправою постало завдання «Оптимальні варіанти» [7, с. 234]. Учасники об'єдналися в групи по 3-4 особи задля розв'язання конфліктних ситуацій. Учасники продемонстрували різноманітні стратегії розв'язання конфліктів: найбільш екологічну (з найменшими витратами сил), впевнену, агресивну та сором'язливу. По завершенню вправи група зробила висновок, що гнучкість у різних ситуаціях дає змогу бути максимально ефективним при розв'язанні конфліктних ситуацій.

Після «Оптимальних варіантів» учасники тренінгових занять виконували вправу «Хто без стільця ?» [6, с. 240]. По колу були розставлені стільці у меншій кількості за учасників тренінгу. Учасники ходили по колу навколо стільців і за сигналом ведучого намагалися зайняти вільні стільці. Хто не встигав вибували, при цьому кількість стільців продовжувала зменшуватися. По завершенню за зворотнім зв'язком від учасників було зроблено висновок, що є сенс тренувати регуляцію поведінки, особливо в умовах невизначеності та мінливості ринку, в яких зазвичай і перебуває менеджер-спеціаліст.

Мета наступної вправи «Хода» [7, c. 216] полягає у розвитку навичок пластичної 
експресії, навчанні саморегуляції, емоційних станів через контроль їхніх зовнішніх проявів, а також розвитку спостережливості і вміння зовні проявляти свої емоційні стани. Учасники обирають емоцію або психологічний стан, який вони хочуть продемонструвати, і проходять перед групою таким чином, щоб за їхньою ходою можна було здогадатися, що саме вона демонструє. Кожному було надано кілька спроб, під час яких необхідно проявляти різний стан. Було продемонстровано такі варіанти ходи, як: упевнена, сором'язлива, агресивна, радісна, ображена та ін.

Вправа «Заборона говорити «ні» [2]. передбачає відпрацювання навичок асертивної поведінки. Один з учасників ставить іншому провокативні запитання, на яке той не має позитивної відповіді. Інший учасник має висловити свою незгоду таким чином, щоб не використовувати слів «ні» або «не» (тільки у позитивній формі). Така вправа дала змогу легше налагоджувати контакт навіть за умови різних поглядів на наявні питання.

Вправа «Перекинь м'яч» має на меті певний рух, а також відпрацювання навичок координації спільних дій; умінь нестандартно мислити в ситуації невизначеності. Учасники перебувають в тісному колі, де потрібно було якомога швидше перекидати м'яч один одному так, щоб він побував у руках кожного. Із кожним разом прискорювався темп. Потім учасники мають придумати і продемонструвати спосіб перекидання м'яча за одну секунду так, щоб він побував у руках у кожного.

Наступна вправа - «Секрет Джованні» [17, с. 338]. Мета вправи полягала у відпрацюванні навичок ефективної кооперації i вміння слухати один одного; вона дала змогу побачити і оцінити роль лідера в команді.

Останнім завданням постала вправа «Звіт за день» (авторська модифікація). Ця вправа мала на меті підведення підсумків, актуалізацію засвоєної інформації та підвищення самооцінки. Учасники записали на папері що їм вдалося за цей день, чим вони будуть користуватися, чого навчилися, основні здобутки і питання, які варто додатково опрацювати. Після цього звіти перемішалися і кожен учасник витяг за жеребкуванням звіт одного 3 учасників групи і підготував урочисту промову на честь цієї людини. У промові необхідно було не тільки визнати усі заслуги, про які йдеться у звіті, а і додати щось від себе, оцінити підтримку і особистий внесок іншого учасника в загальні результати, розкрити його потенційні можливості; за бажанням автор звіту міг додати щось від себе.

Домашнє завдання після другого модулю полягає у вигляді перегляду художнього фільму (на вибір) на професійну тематику, а також напису есе, у якому необхідно зазначити основні чинники успіху головних героїв (менеджерів), а також визначити їхні професійні якості й основні управлінські принципи. Перелік фільмів: «Засновник» (2016), «Стажер» (2015), «12 років рабства» (2013), 
«Стажери» (2013), «А мені б у небо» (2009), «Чумові боти» (2005), «Бойлерна» (2000), «Уолл-Стріт» (1987). Орієнтовний час виконання завдання - три години. Таким чином загальна кількість годин, спрямована на другий модуль розвитку комунікативного компоненту ПЗЯ майбутніх менеджерів становив дев'ять годин.

Третій модуль розвитку комунікативного компоненту ПЗЯ майбутніх менеджерів був спрямований на пошук ефективних стратегій розв'язання конфліктних ситуацій і передбачав шість годин тренінгових занять. Перша вправа третього модулю - Ім'я і асоціація». Учасники по колу називали своє ім'я та якість, асоціацію, характеристику, що починається на першу літеру власного імені. Кожний наступний мав пригадати імена всіх попередніх учасників, а також їхні якості - за принципом снігової кулі. По завершенню учасники пригадували загальні правила і висловлювала власні очікування від тренінгового заняття.

Мета вправи «5 спільних ознак» - об' днання учасників i розширення діапазону сприйняття себе в колективі. Учасники об'єднуються в підгрупи по 3-5 осіб. У кожній підгрупі учасники мають протягом п'яти хвилин знайти п'ять ознак, які їх об’єднують, і на основі них придумати своїй групі назву. Один із учасників презентує всю групу.

Вправа - «Сніданок з героєм», в основі якої напрацювання навичок перемовин, аргу- ментування і відстоювання власної позиції. Рефлексія даної вправи допоможе студентам зрозуміти, наскільки ефективними $\epsilon$ їх стратегіï, а також визначити, дотримання яких саме стратегій у перемовинах допомагає досягати бажаних результатів.

Вправа «Конфлікт і алгоритм дій дала змогу учасникам проаналізувати переваги i недоліки різних стратегій виходу з конфліктних ситуацій та визначити найбільш ефективні $з$ них.

Особливий інтерес викликала вправа «Місток» [7, с. 138]. Мета вправи полягала в пошуку різноманітних стратегій розв'язання конфліктної ситуації, а також в обговоренні ефективності тих чи тих стратегій. Учасники розділилися на пари, стаючи на прямій лінії, проведеній на підлозі, обличчям один до одного на відстані близько 3 м. Завдання - пройти один одному назустріч (як по містку) і в центрі розійтися, при цьому учасник, який поставив ногу за лінію - «впав у воду» і програв. Під час виконання вправи учасники продемонстрували свої стратегії розв'язання конфліктної ситуації, а також обговорили ефективність і самопочуття при обранні стратегій.

Задля закріплення попереднього завдання було використано вправу «Перетягну газету» $[18$, с. 238$]$. Учасників так само було розділено на пари. Пари отримали по газеті, згорнули її в трубочку, стали на відстані метр один від одного, підняли одну ногу і притримували іiі рукою. Вільною рукою вони брали 
трубочку з газети і починали їі перетягувати, прагнучи вивести один одного з рівноваги, але при цьому не порвати газету. По завершенню учасники обговорювали стратегії конфліктної ситуації і виснували, що часто-густо при взаємодії ефективно не застосовувати силу, адже це може загрожувати розривом відносин.

Вправа «Три способи поведінки» передбачала тренування впевненої поведінки [6, c. 233]. Учасники розігрують конфліктні ситуації, в яких їм необхідно обрати різні стилі поведінки: сором'язливий (говорили винуватим тоном, тихим голосом, погоджуватися із запереченнями співрозмовника), впевнений (говорили спокійно, помірковано-голосно, дивлячись прямо на співрозмовника, наполегливо викладати свої вимоги, не вдаючись до звинувачень і погроз), агресивний (говорили голосно, енергійно жестикулювали, вимагали, наказували, погрожували). Кожна ситуація програвалася в парах тричі. Один із партнерів веде себе відповідно до певного стилю, інший - на власний розсуд.

Після вправи «Три способи поведінки» учасники взяли участь у рольовій грі «Конфлікт», мета якої - демонстрація різних стратегій поведінки в конфлікті, а також тренування впевненої поведінки і за необхідності - гри на «публіку» [15, с. 148]. Обов'язкова умова - один учасник загострював ситуацію, а другий намагався вирішити конфлікт.

Далі учасники пройшли вправу «Команди, що змінюються» (авторська моди- фікація). Мета вправи - надати учасникам можливість взаємодіяти в різних конфігураціях, порухатись, виконати певні командні завдання [9, с. 64]. По завершенню вправи всі учасники тренінгу мають згуртуватися і зобразити за допомогою власних тіл слово «конфлікт».

Наступна вправа - «Вміння слухати» формувала навички концентрації уваги на співрозмовнику, без викривлення фактів [18, c. 191]. Учасники об'єднувалися в пари і протягом п'яти хвилин розмовляли, тримаючи зоровий контакт. Необхідно було кожному розказати про власне життя за останні 24 години, при цьому другий учасник розмови не міг нічого говорити. Потім учасники мінялися ролями. По завершенню співрозмовники надавали зворотню реакцію один одному щодо особливостей комунікації, коли кожний учасник має протилежну стратегію взаємодії (активнупасивну).

Основна мета наступної вправи «Вирішення конфлікту» - вирішити запропоновані ситуації згідно етапів вирішення конфлікту за схемою: визначення сторін; окреслення позицій, інтересів та потреб; оцінка і вибір оптимального варіанту; творчість [1, с. 25].

Останнє завдання - «Вправа на завершення тренінгу». Учасники тренінгу надавали зворотній зв'язок щодо відкриття нових знань, умінь та навичок, розкривали власні відчуття та ділилися враженнями щодо нового досвіду, окреслювали напрямки, які варто кожному індивідуально доопрацювати не тільки щодо 
обрання ефективних стратегій розв'язання конфліктних ситуацій, а й в контексті їхнього комунікативного компоненту ПЗЯ загалом.

Висновок. Отже, у статті описано процес розвитку ПЗЯ майбутніх менеджерів організацій засобом психологічного тренінгу, основні психологічні механізми тренінгового впливу на особистість і розроблено на цій основі програму тренінгу який складався 3 трьох модулів і $€$ направлений на виникнення у студентів нового комунікативного досвіду в контексті майбутньої професійної діяльності, та має на меті дати їм змогу напрацювати навички для ефективної професійної взаємодії $\mathrm{i}$ покращити своє уявлення про себе як про майбутнього управлінця.

\section{Подальші перспективи дослідження} доцільно спрямувати на розширення практичної апробації запропонованого тренінгу в експериментальному дослідженні з метою перевірки його ефективності та впровадження психологічного компоненту в процес здобуття фахової освіти.

\section{Перелік використаних джерел:}

1. Андрєєнкова В. Л Навчальна програма «Базові навички медіатора в навчальному закладі та громаді. Забезпечення участі жінок і дітей у розв'язанні кофліктів та миробудуванні»: робочий зошит учасників/ Дацко О.В., Лунченко Н.В., Мараховська Т.А. Загальнаредакція: Левченко К.Б., - 25c.

2. Балахтар $\quad$ B. $B$ Соціально-психологічний тренінг і маніпуляція [Текст] : навч.метод. посіб. / В. В. Балахтар ; М-во освіти і науки України, Буковин. держ. фін.-екон. ун-т. - Вижниця : Черемош, 2015. - 431 c.

3. Баталова Т. В. Личносные детермененанты процесса професилнального становления менеджеров в вузе :авториф. Дис. на соиск. ученой степени канн. псих. наук.,: спец. 10.00.05 «Социальная психология»/ Т.В. Баталова. - М., 2004. - 20 с.

4. Бачинська Ю. П. Особисті чинники успішної діяльності конкурентоспроможного менеджера/ Ю.П. Бачинська//Вісник КІБІТ. - 2008. -№2 - С. 72-74.

5. Вудкок М. Раскрепощенный менеджер: для руководителя-практика / М. Вудкок, Д. Фрэнсис; [пер. с англ.]. М. : МП «Дело», 1991. - 365 с.

6. Грецов А. Г. Тренингразвития с подростками: Творчество, общение, самопознание / А.Г. Грецов, - СПб.: Питер, 2011, - 416 с.

7. Грецов А. Г. Психологическиетренинги с подростками / А. Г. Грецов. - СПб : Питер, 2008, - 368c.

8. Діденко М. Дослідження психологічних особливостей розвитку професійно значущих якостей майбутніх менеджерів організацій//Науковий журнал «Організаційна психологія. Економічна психологія». №1 (12), 2018. - C26-36.

9. Доброскок A. C. Психологічні чинники формування професіоналізму майбутніх менеджерів / А.С. Доброскокдис. на здобуття. канд. психол. Наук19.00.07 - педагогічна та вікова психологія. -К.:2013-217с.

10. Карамушка Л. М. Психологія підготовки майбутніх менеджерів до управління змінами в організації: монографія / Л.М. Карамушка, М.В. Москальов. - К. - Львів: Сполом, 2011, - 216 с.

11. Максименко C. Д. Технології спілкування (комунікативна компетентність учителя: сутність і шляхи формування)/ С. Д. Максименко, М. М. Забродський - К.:Главник, 2005. - 112c. - (серія «Психол. Інструментарій»). - Бібліогр.: с.107-109

12. Максименко С. Д. Механізми трансформації структурних компонентів діяльності у професійному розвитку особистості в сучасних умовах / С.Д. Максименко // Актуальні проблеми становлення особистості професіо- 
нала в ризиконебезпечних професіях: матеріали міжрегіон. наук. семінару, (Київ, 25 березня 2010 р.) / Мін-во оборони України, Національнийуніверситет оборони України. - К.: НУОУ, 2010. - С.12-14.

13. Орбан-Лембрик Л. Е. Соціальна психологія :навч. посіб. /Л. Е. Орбан-Лембрик. Київ : Академвидав, 2005. $-448 \mathrm{c}$.

14. Панченко В. Г. Личность руководителя: учеб. пособие для студентов / В. Г. Панченко, В. Н. Паутов, Т. В. Разенкова. - М.: МАКС Пресс, 2010. - 320 с.

15. Психолого-педагогический практикум: учеб. пособие для студ. вузов, обуч. по спец. «Педагогика и психология», «Социальная педагогика», "Педагогика" Л. С. Подымова, Л. И. Духова, Е. А. Ларина, О. А. Шиян ; под ред. А. В. Сластёнина. 2-е изд., стер. - М. : Академия, 2006. - 224 с.

16. Теймуразян А. Л. Формирование профессионально важных личностных качеств будущих специалистов как педагогическая проблема // Теория и методика профессионально-педагогического образования: Сб. научнометодических работ. - Самара, 2003. - 520 с. - С. 153156.

17. Фопель К. Групповая сплоченность. Психологические игры и упражнения. Пер.снем. - М.: Генезис, 2010. - 336c. ISBN978-5-98563-210-1

18. Фопель $K$. Создание команды. Психологически еигры и упражнения/ К. Фопель, [пер.снем]. -М.: Генезис, $2002,-400$ c.

19. Чепелєва Н. В. Особистісна підготовка психологапрактика / Н.В. Чепелєва // Персонал. - 2000. - № 5 (59): Приложение. - № 10 (15). - С. 17 - 18.

20. Goldberg L. R. The Structure of Phenotypic Personality Traits. Am. Psychol. / LR. Goldberg., 48 (I): (1993) P. 2634.

21. Howard P. J. The Big Five Quick Start: Anintroductiontothe five factor model of personality for human resource professionals/ PJ Howard, JMHoward . - ED 384754, Centreofappliedcognitive studies, Charlotte, NorthCarolina - (1995). P21.

\section{References (Transliteration):}

1. Andrieienkova $\quad$ V. L Navchalna prohrama «Bazovi navychky mediatora $\mathrm{v}$ navchalnomu zakladi ta hromadi. Zabezpechennia uchasti zhinok i ditei u rozv'iazanni kofliktiv ta myrobuduvanni»: robochyi zoshyt uchasnykiv/ Datsko O.V.,Lunchenko N.V., Marakhovska T.A. Zahalnaredaktsiia: Levchenko K.B., - 25 c.

2. Balakhtar $V . V$ Sotsialno-psykholohichnyi treninh i manipuliatsiia [Tekst] : navch.-metod. posib. / V. V. Balakhtar ; M-vo osvity i nauky Ukrainy, Bukovyn. derzh. fin.-ekon. un-t. - Vyzhnytsia : Cheremosh, 2015. - $431 \mathrm{~s}$.

3. Batalova $T$. V. Lychnosnыe determenenantы protsessa profesylnalnoho stanovlenyia menedzherov $\mathrm{V}$ vuze : avtoryf. Dys. na soysk. uchenoi stepeny kann. psykh. nauk.,: spets. 10.00.05 «Sotsyalnaia psykholohyia»/ T.V. Batalova. - M., 2004. - 20 s.

4. Bachynska Yu. P. Osobysti chynnyky uspishnoi diialnosti konkurentospromozhnoho menedzhera/ Yu.P. Bachynska// Visnyk KIBIT. - 2008. -№2 - S. 72-74.

5. Vudkok M. Raskreposhchennыi menedzher: dlia rukovodytelia-praktyka / M. Vudkok, D. Frэnsys; [per. s anhl.]. - M. : MP «Delo», 1991. - $365 \mathrm{~s}$.

6. Hretsov A.H. Trenynh razvytyia s podrostkamy: Tvorchestvo, obshchenye, samopoznanye / A.H. Hretsov, SPb.: Pyter, 2011, - 416 s.

7. Hretsov A. H. Psykholohycheskye trenynhy s podrostkamy / A. H. Hretsov. - SPb : Pyter, 2008, - 368s.

8. Didenko M. Doslidzhennia psykholohichnykh osoblyvostei rozvytkuprofesiino znachushchykh yakostei maibutnikh menedzheriv orhanizatsii// Naukovyi zhurnal «Orhanizatsiina psykholohiia. Ekonomichna psykholohiia». - №1(12), 2018. - S 26-36.

9. Dobroskok A. S. Psykholohichni chynnyky formuvannia profesionalizmu maibutnikh menedzheriv / A.S. Dobroskok dys. na zdobuttia. kand. psykhol. Nauk19.00.07 - pedahohichna ta vikova psykholohiia. -K.:2013-217s.

10. Karamushka L. M. Psykholohiia pidhotovky maibutnikh menedzheriv do upravlinnia zminamy v orhanizatsii: monohrafiia / L.M. Karamushka, M.V. Moskalov. - K. - 
Lviv: Spolom, 2011, - $216 \mathrm{~s}$.

11. Maksymenko S. D. Tekhnolohii spilkuvannia (komunikatyvna kompetentnist uchytelia: sutnist i shliakhy formuvannia)/ S. D. Maksymenko, M. M. Zabrodskyi K.:Hlavnyk, 2005. - 112s. - (seriia «Psykhol. Instrumentarii»). - Bibliohr.: s.107-109

12. Maksymenko S. D. Mekhanizmy transformatsii strukturnykh komponentiv diialnosti u profesiinomu rozvytku osobystosti v suchasnykh umovakh / S.D. Maksymenko // Aktualni problemy stanovlennia osobystosti profesionala $\mathrm{v}$ ryzykonebezpechnykh profesiiakh : materialy mizhrehion. nauk. seminaru, (Kyiv, 25 bereznia 2010 r.) / Min-vo oborony Ukrainy, Natsionalnyi universytet oborony Ukrainy. - K.: NUOU, 2010. - S.12-14.

13. Orban-Lembryk L. E. Sotsialna psykholohiia :navch. posib. /L. E. Orban-Lembryk. Kyiv : Akademvydav, 2005. -448 s.

14. Panchenko $V$. H. Lychnost rukovodytelia: ucheb. posobye dlia studentov / V. H. Panchenko, V. N. Pautov, T. V. Razenkova. - M.: MAKS Press, 2010. - 320 s.

15. Psykholoho-pedahohycheskyi praktykum: ucheb. posobye dlia stud. vuzov, obuch. po spets. "Pedahohyka y psykholohyia", "Sotsyalnaia pedahohyka", "Pedahohyka" / L. S. Podumova, L. Y. Dukhova, E. A. Laryna, O. A. Shyian ; pod red. A. V. Slastënyna. - 2-e yzd., ster. - M. : Akademyia, 2006. - $224 \mathrm{~s}$.

16. Teimurazian A.L. Formyrovanye professyonalno vazhnыkh lychnostnыkh kachestv budushchykh spetsyalystov kak pedahohycheskaia problema // Teoryia y metodyka professyonalno-pedahohycheskoho obrazovanyia: Sb. nauchno-metodycheskykh rabot. Samara, 2003. - 520 s. - S. 153-156.

17. Fopel $\quad K$. Hruppovaia splochennost. Psykholohycheskyeyhrы y uprazhnenyia. Per.s nem. - M.: Henezys, 2010. - 336s. ISBN978-5-98563-210-1

18. Fopel K. Sozdanye komandы. Psykholohycheskye yhrы y uprazhnenyia/ K. Fopel, [per.s nem]. -M.: Henezys, 2002, - 400s.

19. Chepelieva $N$. V. Osobystisna pidhotovka psykholohapraktyka / N.V. Chepelieva // Perso nal. - 2000. - № 5
(59): Prylozhenye. - № 10 (15). - S. 17 - 18.

20. Goldberg L. R. The Structure of Phenotypic Personality Traits. Am. Psychol. / LR. Goldberg., 48 (I): (1993) P. 2634.

21. Howard P. J. The Big Five Quick Start: An introduction to the five factor model of personality for human resource professionals. / PJ Howard, JM Howard . - ED 384754, Centre of applied cognitive studies, Charlotte, North Carolina - (1995). P 21.

\section{Didenko Maryna}

Senior lecturer of Psychology and Personal Growth Department of Educational and Scientific Institute of management and psychology of State Higher Educational Institution "University of Educational Management" of National Academy of Educational Sciences of Ukraine, Kyiv (Ukraine)

\section{DEVELOPMENT OF PROFESSIONALLY SIGNIFICANT QUALITIES OF FUTURE MANAGERS OF ORGANIZATIONS THROUGH PSYCHOLOGICAL TRAINING}

\section{ABSTRACT}

Today, the issue of competitive edge in the employment market is very urgent for Ukrainian graduates. Upon receiving a diploma of higher education, the graduate has some theoretical knowledge that does not always meet the challenges $s /$ he faces in professional life. In our opinion future specialists should look for the development of professionally relevant qualities in order to solve this problem. The article is devoted to the description of the process of guided development of future manager's professionally significant qualities in the process of obtaining higher education.

We propose to develop professionally significant qualities (PSQ) of future managers with 
the help of a specially developed training program aimed at developing the communicative component of PSQ of future managers. This is due to the fact that, firstly, the communicative component itself, on the basis of the results of the factor analysis, has taken the first place in PSQ hierarchy of future managers at all stages of the educational process. Secondly, at the verification stage of the study, the analysis of the results of the expectations of future managers from the profession (according to the projective method) revealed that the majority of respondents see possible problems with communications in the team, with subordinates or management among the greatest difficulties in their future work. Accordingly, we have chosen the communicative component of the PSQ of future managers, as a component which if being influenced will bring future managers to the level of "manager-professional" as quickly as possible.

Taking into account the fact that in the course of educational process it is usually impossible to conduct one multi-day training, as a rule, it is not possible, we consider it expedient to conduct three separate 6-hour modules of social and psychological training (three one-day trainings), as well as two independent homework tasks, which require nine and three hours, respectively. In total development process of professionally significant qualities of future managers requires 30 academic hours, 1 credit, respectively.

The content of the practical training session was designed in such a manner to enable par- ticipants to maximize their communication skills in the format of future professional activities, help them overcome their fears and provide tools for effective communication.

The first module was devoted to the development of communicative skills of students, future managers, the second module was devoted to the development of assertive skills, and the third was aimed at finding effective strategies for resolving conflict situations.

The target audience of our training consisted of the students-managers of the 3-4 year of studies, because at this age that the impact on the development of the student's personality is the most effective, adaptation to the training process has already been completed, and the image of a future professional is beginning to emerge.

Thus, the article describes the development of PSQ of future managers of organizations by means of psychological training, basic psychological mechanisms of training effect on the person and as the result new training program has been developed, it consists of three modules and aimed at the emergence of the new communicative experience in the context of student's future professional activity, and it also aims to enable them to develop skills for effective professional interaction and to improve their perceptions of themselves as future managers. Further investigation is to be focused on expanding practical testing of the proposed training in the pilot study to test its effectiveness and implementation of the psychological component in the process of ob- 
taining professional education.

Key words: personality quality, manager students, professionally significant qualities, psychological training, communicative component.

\section{Диденко Марина Сергеевна}

Стариий преподаватель кафедры психологии и личностного развития Учебно-научного института менеджмента и психологии Государственного высшего учебного заведения «Университет менеджмента образования» Национальной академии педагогических наук Украинь, г. Киев (Украина)

\section{РАЗВИТИЕ ПРОФЕССИОНАЛЬНО ЗНА- ЧИМЫХ КАЧЕСТВ БУДУЩИХ МЕНЕ- ДЖЕРОВ ОРГАНИЗАЦИЙ СРЕДСТВАМИ ПСИХОЛОГИЧЕСКОГО ТРЕНИНГА}

Аннотация. Статья посвящена описанию процесса управляемого развития профессионально значимых качеств будущих менеджеров в процессе получения высшего образования. Предоставляются организационнометодические рекомендации по организации и содержательного наполнения тренинговой программы. Процесс организации и проведения тренинговых занятий со студентамименеджерами в процессе обучения. Акцент в тренинговой программе сделан на развитие коммуникативного компонента профессионально значимых качеств будущих менеджеров, в связи с тем, что большинство респондентов при констатирующем эксперименте именно в нем видят наиболее значимые пробелы своего развития и придают ему первостепенное значение прогнозируя свою будущую деятельность. В статье описано три мо- дуля тренинговой программы направлены на три содержательных компонента: развитие коммуникативных умений, ассертивности и стиля реагирования в конфликтных ситуациях, рассчитанные на три однодневных тренинги и ряд домашних заданий.

Ключевые слова: эмпатия, сочувствие, сопереживание, механизмы эмпатии, тревожность, интернальность.
Дата отримання статті: 21.05.2018 Дата рекомендації до друку: 11.06.2018 Дата оприлюднення: 02.07.2018 